UDC: 005.336.3:339.138

COBISS.SR-ID: 211604236

Original research paper

Acta Agriculturae Serbica, Vol. XIX, 37 (2014);15-26

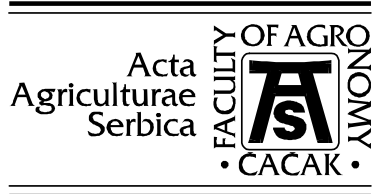

\title{
Quality Management System in Trade - Internationalisation of Marketing Relations with Consumers
}

\author{
Gvozden Jovanović \\ e-mail: gvozdenjovanovic@hotmail.com \\ Katarina Marković \\ Department of Economics, Rayerson University, \\ 350 Victoria St Toronto ON M5B2K3 Canada \\ e-mail: katarina.markovic@ryerson.ca
}

\begin{abstract}
The aim of marketing management is to satisfy the needs and desiers of consumers. A lot of factors have influenced the consumers and their purchasing. Besides price and assortment factors there are requerements of consumers for the qualitiy of a product. It means that a product should possess physical, chemical, designing, aesthetic, ecological and other desirable properties that should be expressed before the use of products. Because of that the quality in the theory and practice of managment is beginning to affirm itself. This has been particularly expressed by the introduction of ISO 9000 which makes internationalistion of quality system and circulation of goods and services without "physical-fiscal-technical" barriers possible.
\end{abstract}

Key words: internationalisation, trade, consumer, quality, marketing, management, ISO 9000(QMS), ISO 14000(EMS), TQM. 


\section{New Management Paradigm: Marketing Trade Relationship with Consumers Based on Quality}

The understanding that the company's succes primarily depends on the rational use of production factoes, productivity, mass production and cost has long been present in theory. Today this attitude is still not at stake, it is even actualized to the extent to which the factors of production-line goods are expensive and limited. However, marketing-oriented companies in their philosophy of business realized the fact that quality is one of the alternative ways to maintain existing and obtain a better strategic position in the market.Survival in the market will bu provided only for those companies which are able to outperform competitors, and that means being able to offer true quality products and services in the right place and the right way, that is to operate on the principle of "just-in-time". In the beginning, the companies insisted on product quality, its functional properties, not on content and expectations of the psychosocial and status dimension. With the development of marketing concepts company will also highlight the need to comprehensively approach the problem of quality and that it is included in all business activities on the whole, that is in an integral way.

The focus of this incredible boom is the customer with his requests, needs and desires. If the quality implies a set of specific properties that meet customer needs, then one can conclude that it has its Individualize dimension. With quality products and services of individual observations and views are of special value because they answer the company's question of which product characteristics are essential, contradictory and less relevant in a given time and cultural environment. The key factors here are: a) the economic power of the buyer, b) education, c) culture, d) religion, e) personality and personal value system. External influences come from the environment through different information and different entities: customers, suppliers, banks, research organizations, competitors, public media and others. Consumers are increasingly oriented to buying organic products, labeled "natural." They are willing to pay for such expensive products. It is therefore a wider range of demands by customers, concerning the quality of goods and services they buy. So it is not coincidence that the marketing literature in recent times has often discussed the conclusion that quality is what customers say that the quality, not what the manufacturers and the trade say it is. In fact, to find out more about our quality products and services, it is best to ask customers. Satisfied customers will buy our product again and have nice things to say about it. Hence the saying "a satisfied customer is the best advertisement." The fulfillment of these requirements is a measure of the success of marketing strategy of a company (Kotler, P. 1997.) It is this 
subject platform that studies of these problems are designed from. It is intended to provide an answer to the question - What constitutes a quality management system in the trade (QMS)? How to achieve the marketing mix of functions and other aspects of quality in the trade? How to provide quality products and services in trade from the point of use value (quality range)? How to achieve quality of service activities in accordance with the requirements of consumers? How to provide customers with products labelled "eco", "natural" and "healthy"?

As a logical continuation of the research, the question of trade relations and eco-standards ISO 14000 and the instrumentalization of eco-marketing in trading (eco-mark and eco-packaging) arise. The European Union has actualized and internationalized this issue by establishing quality standards ISO 9000 (ISO 9001:2000 QMS) and eco-standards ISO 14000 (EMS-ISO 14001:2004). (Sheps, I., 2008.)

\section{Marketing Strategy in Trade Quality - New Model of Brand Construction}

Most of the production of goods, especially consumer goods is carried out through trade. In fulfilling the role of intermediary, the trade is exposed to the demands of millions of consumers army. As such, it is not a passive mediator between producers and consumers. Each "forgetfulness" of trade in relation to its consumers, whether in terms of range, quality, or services is an anti- marketing act. In order to be accepted by consumers, productsof a company's portfolio should meed the requirements of quality, in addition to those of desing and price.The consumer is that" king" he requires a high level of quality products and services for a price. Gone are the days when consumers bought goods exclusively at their own risk.Today, that risk is borne largely by trading companies and manufacturers. The customer market provides the consumer with sovereignty by putting him in position to express own his preferences by buying products from the "Offer package " of a trading company that offers a higher level of product quality and serving quality serving than its competitors.

Trade must behave as a consumer advocate with the manufacturer. Only a satisfied customer may remain loyal to a particular business enterprise. This implies a continual adjustment of the trade the changing human needs and desires of consumers, through the innovation of the portfolio. In that respect, quality innovation of the "offer package" of commercial enterprise is particularly important.The existence of quality standards is the best protection for consumers and traders from careless and incompetent manufacturers. In this light there is the need of cooperation between business partners and qualitative formation of "package" of the total offer.The European Union has actualized and internationalized this issue by establishing quality standards ISO 9000 (QMS) and eco-standards ISO14000(EMS). Trade market experience of developed countries tell us that there is no successful marketing in the trade, without a 
reliable quality products and services. On the horizon is the process of creation of a new market philosophy that quality is one of the alternative ways to preserve existing and obtain a better strategic position in the market. Survival in the market will bu provided only for those companies which are able to outperform competitors, and that means being able to offer true quality products and services in the right place and the right way, that is to operate on the principle of "just-intime". Consumer's expectations about quality are various. In poor markets these expectations are increasingly reduced to the elemental nature of the product, and less on the aesthetic properties, delivery on time delivery to customers home and so on. In developed market economies with a high standard and level of consumption consumers' expectations are more refined, more cultivated, and most importantly they are expressed in a wide range of requirements. In addition to functional properties (durability and usefulness) the consumer also wants to like the goods offered. Although these properties are not from the point of use, of primary importance, having a nice pleasurable goods makes the consumer pleased. Therefore, the concept of quality in trade expands to the area of aesthetics. Such requirements impose, the need tonot only constantly maintain the achieved level of quality upon the trade management, but to increase it as well: innovation in product assortment, improving style serving, improving the external appearance and interior design shops, preparedness goods for sale, behavior and appearance of sales personnel and communication culture. It is the affirmation of TQM in the trade.

\section{Marketing Mix of Qualitative Properties of Products and Services to Meet Customers}

The scientific literature has accepted the thesis that a trading company will survive in the market if it is oriented to customers. Philip Kotler elaborating this thesis, writes: "To win in today's marketplace, companies must be customer oriented, provide superior value to their target buyers. They must be skillful in the creation of customers, not creating products." Peter Drucker, a leader in the field of management theory and entrepreneurship emphasizes the importance of creating value for customers and says: "The goal of every company is making consumers and conquest of the market.These are the two main entrepreneurial functions. " The marketing management of a trading company sees the quality as a prerequisite for the succesiful operation of enterprises and creation of the competitive advantage. Adapting to the demands of consumers for the quality, trade management should create a "offer package" combining: quality products, quality servicing, quality installation, quality of service and quality maintenance. Thus designed procedures are based on the quality of customer value "package deals" with respect to economic principles (cost/ costs). 
The marketing function is also supposed to establish a system for continuous monitoring and collecting information. All information relating to the quality of products or services should be analyzed, processed, explained and communicated to the appropriate functions in accordance with established procedures. Such information will help to determine the nature and severity of the problem related to the product or service in relation to the consumer's experience and expectations. Competition as an important factor in the market, often offes equivalent products and services of similar levels of performance and quality, creating such a market condition that determines the significance of other market factors. Institutions to protect markets, such as consumer associations, environmental movements and other organizations, for infringing the expected level of quality are put into action. The effect of these institutions can be of great importance to the market position of products. Some products may even be prohibited from sale in the case of falure to observe required safety or other standard regulations. The marketing function at the same time should allow the market to test the readiness to accept new or innovated products. Depending on the type of product, testing may include the following: a) the availability and acceptability of technical instructions for installation, operation, maintenance and repair, $b$ ) the existence of appropriate organizations to distribute and service the customer, c) training staff to use and maintenance products, $d$ ) availability of spare parts and e) testing the service. Some polls suggest consumers are willing to purchase ecoproducts in allocaring $6 \%-10 \%$ more money than for traditional ones. For this purpose, the contemporary conditions of competition in trade bring to light the latest forms of competitive tools. To highlight the quality of ecoproducts that occurs before the eyes of consumers, the management of hypermarkets "FIESTA" Houston (Texas) has decided that the hypermarket of $22,000 \mathrm{~m}^{2}$ on four floors accommodate a garden in which vegetables grow before the eyes of the consumers from the water,with no land at all (Brown, A., Loughton, K., 2001.) without artificial fertilizers and pesticides Not only are the physical needs of consumers met, but the hidden needs of there psyche are met as well. At the level of the subconscious those roles are sought for that consumers play in their lives, which are related to the offer range of a particular store (Cude J., 2003.). The aim is to provoke a reaction, "when I purchase in a store $\mathrm{X}$, I feel as a wife and mother, and when you buy in a store $\mathrm{Y}$ feel like a woman ' It is obvious that this competitive tools can lead to very successful differentiation of the quality of offers in the eyes of consumers.

\section{Loyality of consumers as a measure of quality}

Combining the available elements is always done according to the selected target groups of consumers. On this basis, there are certain marketing strategies of trading companies. Changes in quality are one of the alternative ways to 
maintain existing and obtain a better strategic position than that of the competition. The emphasis is to create a preference among consumers for the benefit of portfolio that the firm offers. Each feature of quality products and services offered has a specific weight in the creation of the total supply of commercial enterprise. Marketing mix as a result of their optimal combination has to be adapted to the selected market segments. It is a process that is manifested in the trade with much more specificity than in manufacturing. For example, while certain characteristics of quality, in terms of functionality, use and safety products, have a primary, some other properties are of secondary importance. Since a function of use value and satisfaction of consumer needs is onlyfound in sold goods, external appearance and other aesthetic properties may in certain market conditions, be given the primary importance. In this regard, illustrative are observations according to which "it's not uncommon for products whose quality factory made satisfactory, but their conception and design is unsatisfactory to go bade in the market. This means that the product is first class on the basis of factory made need not be first class product on the market " (ISO/TC/SC2/N376, 2006). In other words, the product quality as perceived by consumers is a set of physical, structural, environmental, aesthetic, and many other features that come into play when using. We should bear in mind the service of commercial enterprise as an element in the determination of the consumer to purchase. This gives grounds to, when it comes to quality in the trade, talk about the unity of the quality of the product (range) and quality of services. Therefore, a marketing-oriented management of commercial enterprises must not only force the functional or service component, but to accept them in mutual unity as well. The consumer always wants to get a quality product and to be nicely served for the same price.

\section{Quality Management System in Trade-Integrated Value Chain of Different Stakeholders}

In order to be accepted by the consumers the products range of a trade enterprise should meet the customer requirements concerning apperarance price and quality. This means that a balance between the needs and demands, on the one hand, and the capabilities manufacturers, on the other side is estabilished. The above equilibrium can not be achieved if the manufacturing and trading companies do not cooperate. Joint planning of production and sales range is the best reflextion of the marketing unity of production and trade enterprises.

\section{Customers' satisfaction - the starting point in the strategy (QMS) trade}

The first and the most important task to be solved in the policy portfolio is to identify consumer demands in terms of qualitative characteristics of the product. 
It is necessary to determine which features of quality consumers will give priority to. What should a product mean to customers? What problems should it solre for them? Decisions to buy products include selecting among numerous functional, structural and aesthetic properties."Functional properties are related to the benefits expected from the product: for example,a raincoat should be waterproof; a clock should tell the correct time (and more recently perform other functions - displaying the date, etc.).. Functional properties products(and consumer benefits associated with them) can be achieved in various ways, through various structural characteristics. Structural features include factors such as size, shape, form, color, material, taste, smell and tangible quality. The range of options within each local property of a product is large and the number of possible combinations is almost endless. Minor structural differences in product quality can often serve as a market maneuver to win consumers. Aesthetic features include design, shape, color and other, less clearly distinguishing features that should attract the attention of consumers and contribute to the creation of an attractive and risually enticing produst (Hartman, N., 2009.). It is obvious that a trading company has to take into account the requirements of increasingly choosy consumers and to be adjusted to them.Even minor changes in the composition or package, can increase sales volume because of its greater attractiveness contribute to a visually appealing and attractive product, higher promotional abilities, easier use of the product or provide a greater protection of the content. The product can sometimes get a quality innovation by changingits packaging, especially if the packaging has a functional use beyond the protection of goods .. It should also be noted that the packaging color can lead to certain positive or negative effects for consumers. Colors can cause certain feelings and stimulate the association's attention and associations. The black for instance, can make household electric appliances have a special character, safety and cleanliness.. Black as the dominant color in the package causes a sense of sadness. It is easy to notice dust on a black box so a black package may look dirty and repulsive (Senica, R. 1993.).

\section{Marketing Partnership of trade and manufacturers to overcome the "secrets" of quality management system (QMS)}

Optimal quality, seen as a whole, can only be the result of joint efforts and cooperation of all participants in the cycle of creating a product. It is understood that production is central in this cycle, but it can not solve quality problems (particularly for the quality range) without close cooperation with the trade and consumers. The producer, starting from procurement of raw materials, through the technological process and the final placing the product in the market and on to the consumer, must follow the channel through which a product travels. The production must comply with the existing legislation, regulations and norms of 
its own production, to make the product capable of satisfying consumers demands. This created a series of standards ISO 9000 (QMS) which regulates all activities to be undertaken, in order to achive an international recognitional of the company and its producy. These activities include: a) marketing research market in terms of needs and demands of consumers, b) development projects (specification and product development), c) acquisition of adequate reproductive material, d) planning and development process, e) production, f) monitoring, testing and verification, g) packaging and storage, $\mathrm{h}$ ) sales and distribution, i) installation and commissioning, j) technical assistance and maintenance, $\mathrm{k}$ ) recycling and industrial destruction of environmentally hazardous products (ISO 9000:2000, 2005.). By undertaking these we enable the products to appear at the market and define: the obligation of unification product (shape, dimensions, etc..),product safety in the use and environmental requirements. Thus the constraints of national markets are removed and a free international market, based on flexible contractual relationships of producers and consumers is created. This prevents the marketing of products that do not meet prescribed standards of quality, and consumers are given the opportunity to conduct a proper selection of products. This means that social or economic recognition of the quality of the product is given by the consumers - the market.

Trade needs to have products of the quality that the market or certain categories of consumers are looking for. Therefore,the management of a trading company has to procure and sell quality products that meet their requirements. Failures in the qualitative structuring range are accompanied by frequent sales, excessive inventory and often permanently lost customers. On the other hand, unnecessarily tying funds to the goods with a low turnover coefficient equals the collapse of the company. In most cases the purchase as a trade function is responsible for qualitative structuring of the range. By procurement market research we find out whether the market has goods of the required quality, what kind of prices there are, who the suppliars are, what delivery terms are and so on. Often, commercial businesses have a number of alternatives in determining the source of procurement, and therefore in practice resort to choosing the best suppliers, non pricing criteria deserve an increasing attention, among which the quality is the most important on. Trade can in many ways affect the quality range. It primarily depends on the extent of its involvement in the policy process range. Practice shows that most of the advertised products in the store a result of poor quality in manufacturing. That resulted in the appearance of conflict between producers and shops. Usually one side accuses the other that is not sufficiently understand or that does not respect the real problems. Along with these emerging problems will be solved in order to meet one common goal, the satisfaction of consumers. In such conditions, long-term and firm cooperation of trade and manufacturer becomes a guarantee that consumers have the products of 
required quality. How to establish such cooperation, the central question to be answered.

Modern commercial practice in this respect, the answer to the concrete experiences of a number of commercial firms. Studies have shown that the most successful illustration of joint planning quality assortment we have the example of Marks Spencer end "where the Harvard Business School did a special study as an example of" best-selling "in the American business schools (Lovreta, S., 2008.). Long-term and strong cooperation with the manufacturers base the success of these trading companies. Their relationship goes beyond commercial relations. So zajedištvo allows them four vital things that are necessary in creating a good quality product range, which are: a) analysis and monitoring of final demand in order to prompt manufacturers supply the necessary information, b) the provision of technical product-which can be the basis for cooperation between producers and trade in the field of innovation, improve product quality and reduce costs, c) achieving a complete quality control of products and d) control of raw materials, and provide reliable, high-quality sources of supply (supplier) (Ćuzović, S., Ivanović, P. 2010.). It is, in fact, the direct involvement of commercial enterprise "High end Spencer (MS) in rezrešavanju many issues of technical and technological nature in the process of creating a product.To guarantee the quality of products trading company, and is irrelevant to the consumer who is the manufacturer. The consumer knows only the "MS" his brand "Saint Michael" that has become synonymous with quality consumer products.

Procurement policies in this company is different from the standard practice of other commercial enterprises. Do not purchase products that are already produced, but this company together with the manufacturers engaged in the entire production process according to established specifications. In their specifications, which suggests manufacturers "MS" not only determines the size and deimenzije products, but also the materials of which will be produced and in which technological process. Along with that, the company implements total quality control, not just the final inspection when the goods are produced. It is the kind of management style and strategy, market positioning, which is expressed in the entire process of quality control of all elements of the "package" deals. From this has grown quality management, which is characterized by active role of all employees in the implementation of clearly defined philosophy of quality management system.

\section{Aesthetiyation of Quality Management in Commerce}

Consumers in making decisions about buying products, in addition to the presented qualitative properties, increasingly take into account the quality of services for trading companies. Retail facility location, external and internal 
appearance, landscaping and ambient culture of communicating the sales staff are of prime importance for the reputation and sales trading company. The consumer is interested to hear from the seller for use, product reliability, differences in relation to similar products of other manufacturers, warranty and service. As a result, for any economic activity is not as substantial cooperation in trade and consumers with producers as is the case with the provision of retail services. So there is a need to define the interests of consumers and community goals and interests with manufacturers and trade in terms of quality of services that they provide (Consumer Protection Program for a period of 2007.- 2012, 2007.).

\section{Conclusion}

To this end, manufacturing and trading companies to jointly plan and provide sales service to consumers. As an immediate perpetrator is most common trade, given the place which has a playback. In the interest of consumers is that their objection to having the quality of products said the store. On the other hand, the trade should be in constant cooperation with the manufacturers to 1) assume any liability for the proper functioning of complex technical and expensive products, 2) to organize customer service and technical support services to consumers, 3) to provide spare parts, 4) to organizedelivery of goods to the apartment, its installation, commissioning and 5) to inform consumers about the latest scientific and technological developments relevant to the provision of quality services As the highest level of application of modern scientific and technical progress in raising the quality of service at the store, I should mention computerization and on this basis, information technology trade. It significantly contribute to the information standards (BAR-code) that can be read using an automated reader-scanner. By using a unique encryption product and its scanning increases the level of quality and sales services.Direct connection of electronic (scanning) point of sale cash registers, the terminal allows computers-ized collection of store, called. POS (point-of sale system), electronic transfer of funds so. "EFT POS" system, EDI and Internet. It is evident that consumers are increasingly vocal in their demands for improved services offered by trade. With the implementation of ISO 9000, ISO 14000, HACCP, the CE mark, comes to the fore the quality management system in terms of technical, technological and environmental demands of consumers. Quality management system in the store is moving towards quality service (Ćuzović, S., Sokolov, S., 2009.). However, the quality of services in terms of traditional quality components, such as: location, external appearance and internal sales facility, the ambient spatial planning, culture, communication and sales staff, etc.., Shifts to quality electronic service The quality of electronic services, and general e-commerce, will have a central role in future trade, which will take place over the Internet. 
This gives grounds for assuming that our trade management to go to meet global trends and look for solutions that this development opens.

\section{References}

Brown, A., Loughton, K., 2001. "Smaller enterprises experiences with ISO 9000", International Journal of Quality Management, Vol. 15, No 3.

Consumer Protection Program for a period of 2007.- 2012 (2007), Fig. Gazette RS, No. 11.

Cude J., 2003. Consumer perceptions of environmental marketing clans: as exploratory study, Journal of Consumer Studies and Home Economcs, Vol. 12, No. 3,

Ćuzović, S., Ivanović, P. 2010. Innovation in retail management, Faculty of Economics, University of Nis.

Ćuzović, S., Sokolov, S., 2009 . Improving the quality of electronic services on customer satisfaction, Economics, No.2, Nis.

Hartman, N., 2009 . Aesthetics, Prometheus, Novi Sad.

ISO/TC/SC2/N376, 2006. "Principles of quality management and their application", b) Bianchi, S., (2006), management processes, Mechanical Engineering, Kragujevac.

IS O 9000:2000, 2005. Quality management systems-Requirements, ISO 14001:2004, Systems

Environmental Management-Requirements with guidance for use, FSO, Belgrade.

Kotle r, P. 1997. Marketing Management: Analysis, Planing, Implementation and Control, Prentice Hall, New York, 1997., P. 224

Lovreta, S., 2008. Trade Management, Faculty of Economics, Belgrade, p. 349.

Sheps, I., 2008. Integrated system management, quality, no. 9-10/2008, Belgrade, p. 11.

Senica, R. 1993. Managing growth and development, modern administration, Belgrade. 


\title{
SISTEM UPRAVLJANJA KVALITETOM U TRGOVINI- INTERNACIONALIZACIJA MARKETINŠKOG ODNOSA S POTROŠAČIMA
}

\author{
Gvozden Jovanović \\ e-mail: gvozdenjovanovic@hotmail.com \\ Katarina Marković \\ Department of Economics, Rayerson University, \\ 350 Victoria St Toronto ON M5B2K3 Canada \\ e-mail: katarina.markovic@ryerson.ca
}

\begin{abstract}
Rezime
Marketinški usmerenom menadžmentu trgovinskog preduzeća u prvom planu je zadovoljenje potreba i želja potrošača. Osim nezaobilaznog pitanja cena i asortimana, u kompleksu tražnje nalaze se i zahtevi potrošača u vezi $s$ kvalitetom proizvoda koje kupuju. Reč je o sveukupnim fizičkim, hemijskim, konstrukcijskim, estetskim, ekološkim i drugim obeležjima koja dolaze do izražaja pri upotrebi proizvoda. Kao rezultat toga, u teoriji i praksi počeo se afirmisati menadžment kvaliteta. To posebno dolazi do izražaja uvođenjem serije standarda kvaliteta ISO 9000(QMS) i ISO 14000(EMS). Njima se otvaraju mogućnosti za afirmaciju (TQM) u trgovini, internacionalizaciju sistema kvaliteta i kretanja robe i usluga bez "fizičkih-jezičnih-tehničkih" prepreka.

Ključne reči: internacionalizacija, trgovina, potrošač, kvalitet, marketing, menadžment, ISO 9000(QMS), 14000(EMS), TQM.
\end{abstract}

